\section{A micro-method for measuring glucose using the Autoanalyzer and glucose-oxidase}

\section{CYNTHIA WINCEY AND VINCENT MARKS From the Department of Chemical Pathology, King's College Hospital Medical School, London}

Current methods for the estimation of glucose concentration in body fluids using the Autoanalyzer employ non-specific colour reactions. We have therefore devised a procedure using glucose-oxidase which permits of the determination of true glucose concentrations with this instrument. Glycolysis is prevented by the addition of formalin. The reagents for each estimation cost approximately $1 \frac{1}{4} \mathrm{~d}$.

\section{REAGENTS}

1 SODIUM ACETATE BUFFER $0.5 \mathrm{M}$ Add $40 \%$ sodium hydroxide to about $800 \mathrm{ml}$. distilled water containing approximately $30 \mathrm{ml}$. glacial acetic acid until the $p \mathrm{H}$ is

Received for publication 30 January 1961.
5.0. Add water to bring the volume to 1 litre and recheck the $p \mathrm{H}$.

2 o-TOLIDINE One per cent in absolute alcohol.

3 PEROXIDASE ${ }^{1}$ Use $20 \mathrm{mg}$. per $100 \mathrm{ml}$. in acetate buffer. Reagents 2 and 3 are stable for several months in the refrigerator.

4 BUFFERED ENZYME-DYE REAGENT This is made up of reagents 1,2 , and 3 . To about $80 \mathrm{ml}$. buffer add $5 \mathrm{ml}$. peroxidase solution, $1.0 \mathrm{ml}$. o-tolidine solution, and 1.0 ml. Fermcozyme. ${ }^{2}$ Make up to $100 \mathrm{ml}$. with buffer. This reagent is stable for up to one month when refrigerated. It enters the instrument through tube 5 .

5 FORMALDEHYDE $0.1 \%$ Mix $0.25 \mathrm{ml}$. $40 \%$ formaldehyde and 1,000 units heparin in $100 \mathrm{ml}$. water. This should be prepared each week.

6 GLuCose STANDARDS Dissolve $2.5,5.0,10,20,30$, 40,60 , and $100 \mathrm{mg}$. glucose per $100 \mathrm{ml}$. in saturated benzoic acid.

\section{PROCEDURE FOR AUTOANALYZER}

The determination is performed on the Autoanalyzer using the manifold shown on the flow chart (Fig. 1). If

'Peroxidase P.O.D. Boehringer.

'Fermcozyme, Hughes \& Hughes, 35, Crutched Friars, London, E.C.3.

FIG. 1. Flow chart for Autoanalyzer.

\begin{tabular}{ccc} 
Tube No. & Size $($ in. internal diameter $)$ & Flow $(\mathrm{ml} . / \mathrm{min})$. \\
\hline 1 & 0.040 & 0.6 \\
2 & 0.045 & 0.8 \\
3 & 0.045 & 0.8 \\
4 & 0.056 & $1 \cdot 2$ \\
5 & 0.090 & 2.9
\end{tabular}

Recorder

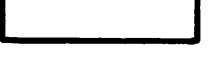

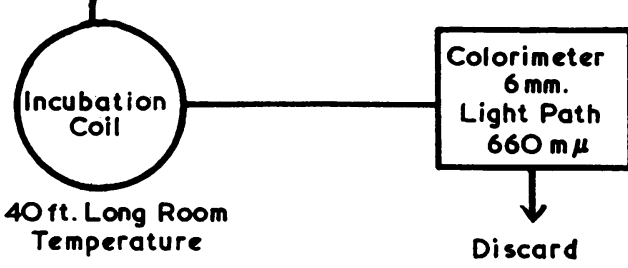

Sample

Air

Air

Water

Buffered Reagent Pump 
necessary, 2 drops of Tween 20 per litre may be added to the water in the recipient stream to ensure a good bubble pattern. Thirty determinations per hour are performed by operating the sampling module at 60 per hour and alternating samples with cups of water.

Colour development varies with the ambient temperature and when large numbers of estimations are performed standards should be run about every two hours. This may not be necessary if a constant temperature bath regulated at $25^{\circ} \mathrm{C}$. is used. Colour development is poor at $37^{\circ} \mathrm{C}$.

The results are read from the graph constructed from the standards using a chart reader and making allowance for dilution.

\section{DETERMINATION OF GLUCOSE IN BLOOD AND CEREBROSPINAL FLUID}

CAPILLARY BLOOD OR C.S.F. Add $\mathbf{0 . 2} \mathrm{ml}$. blood or C.S.F. to $0.8 \mathrm{ml} .0 .1 \%$ formaldehyde solution in a sample cup. This permits of two determinations being made on each sample if required, or allows for further dilution when values above $500 \mathrm{mg}$. $/ 100 \mathrm{ml}$. are encountered; when this is unlikely $0.1 \mathrm{ml}$. blood diluted with $0.4 \mathrm{ml}$. formaldehyde suffices.

VENOUS BLOOD OR C.S.F. Heparinized or oxalated blood or C.S.F. may be preserved by the addition of $0.02 \mathrm{ml}$. $20 \%$ formaldehyde per $\mathrm{ml}$. (the error due to dilution is insignificant). The blood or C.S.F. is diluted 1 in 5 with water when convenient.

Sodium fluoride in amounts sufficient to prevent loss of glucose through glycolysis was found to inhibit the colour production to a variable extent. Formaldehyde in the quantities used prevents loss of glucose for at least 24 hours even at $37^{\circ} \mathrm{C}$., and does not interfere with the reaction.

The reproducibility of the technique was determined by performing 10 estimations on a single blood sample. The mean glucose level was $99.1 \mathrm{mg} / 100 \mathrm{ml}$. Standard deviation was $1.73 \mathrm{mg}$./ $100 \mathrm{ml}$. (range 97 to $102 \mathrm{mg}$./100 $\mathrm{ml}$. .). In a series of experiments the recovery of added glucose was 97 to $104 \%$.

Using the chart reader, glucose values between 12.5 and $500 \mathrm{mg} . / 100 \mathrm{ml}$. can be read acurately; over most of this range Beer's law is complied with.

\section{DETERMINATION OF GLUCOSE IN URINE}

The presence of inhibitory substances in urine which are not removed by dialysis makes it necessary to decolorize with activated charcoal before analysis. When amounts of glucose less than $100 \mathrm{mg}$. $/ 100 \mathrm{ml}$. are present, add 20 to $50 \mathrm{mg}$. activated charcoal to about $2 \mathrm{ml}$. urine in a sample cup, stir, and allow to settle. If larger quantities of glucose are present the urine is first decolorized and then diluted with water to give a final glucose concentration of 5 to $100 \mathrm{mg} . / 100 \mathrm{ml}$.

The recovery of added glucose from urine was 93 to $112 \%$.

\section{A micro technique for protein concentration suitable for quantitative electrophoresis of cerebrospinal fluid}

\author{
J. COLOVER ${ }^{1}$ From the Middlesex Hospital \\ Medical School Institute of Clinical Research, \\ and the Department of Neurology, Middlesex \\ Hospital, London
}

A simple apparatus has been devised for concentrating $0.5 \mathrm{ml}$. samples of cerebrospinal fluid sufficiently to enable quantitative electrophoresis for proteins on cellulose acetate to be undertaken subsequently (Colover, 1961).

It uses a principle described by Miyamoto, Anan, Arai, Sakagiski, and Nomiyama (1957) and Kohn (1959). The method is designed to avoid precipitation of proteins or drying them on a membrane, so that they may be recoverable in maximal amounts with the minimum of qualitative or quantitative change. It might thus be suitable for immunoelectrophoresis or for concentrating other biological fluids available in small quantities. Tests on one of the early prototypes of the apparatus showed that $81 \%$ to $86 \%$ of the protein, estimated by the Lowry, Rosebrough, Farr, and Randall (1951) method was recovered from it. The more recently developed chamber described here is an improvement on this earlier type as

${ }^{1}$ Member of the external scientific staff, Medical Research Council. Received for publication 16 January 1961.

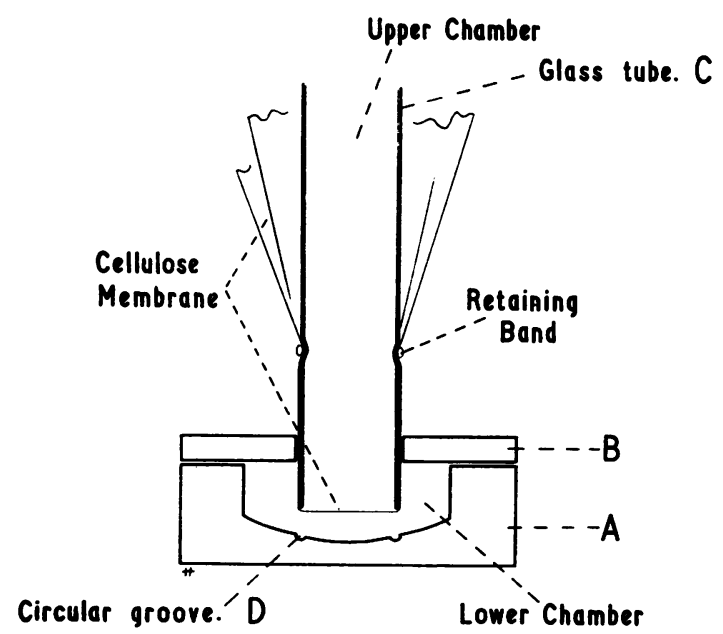

FIG. 1. The concentration chamber (not strictly to scale.) 